\title{
Morphological Study of Residential Real Estate Development in Urban Fringe (Case study: Tunggulwulung Urban Village, Municipality of Malang)
}

\author{
Angga Perdana*
}

\author{
Department of Architecture, Institut Teknologi Sepuluh Nopember, Surabaya, Indonesia. \\ *Corresponding author. Email: anggaperdana.18081@mhs.its.ac.id
}

\begin{abstract}
In the last two decades of the 21st-century residential real estate development in the municipality of Malang has increased rapidly. The urban fringe has chosen for the development location because of the availability of vacant land, and the situation in this area is not too crowded. The lower land value makes the urban fringe feasible to be developed as a residential real estate area. Tunggulwulung is one of the urban fringes in the Lowokwaru sub-district, and this location is not too far from Lowokwaru downtown. This area is strategic for the development of residential areas. To find out the pattern and characteristics of the real estate residential development process, we need a morphological study. The periodization of morphological study limitations on this study is from 2003 to 2019 . Through this research, we will know the trend and culture of real estate development in the urban fringe, especially at Tunggulwulung urban village. From the study, we know that the new residential real estate development in this location increased significantly in 2006-2011. The pattern trend of the residential form is linear and compact forms, and the shape is square, rectangular-shape, fanshaped, and unpatterned shapes. The largest residential real estate that had been developed was Permata Jingga. Furthermore, the new formal settlement has developed on several intercity roads. The most rapidly developed area in this location is in the southeastern region, and it caused by near distance from the central business area, it is the urban culture of the metropolitan city in Indonesia that new residential area was developed at near the downtown and intercity roads. The increasing value of residential real estate land areas between 2003 until 2019 was $112.8 \%$. Today, $52.3 \%$ of the total area in Tunggulwung urban village was developed as a residential area.

Keywords: Morphology, residential, real estate development.
\end{abstract}

\section{INTRODUCTION}

The most frequent problem that always exists in developing countries is the availability of residential land. Most cities in Indonesia are growing rapidly; those have become the destination of migration for the communities to obtain an education, employment, and entertainment. It has caused an increase in population density rapidly in the last decade. That causes a high demand for residential housing.

In the second decade of the 21st-century, the development of the municipality of Malang has been growing rapidly. It has begun to be crowded with commercial areas, education, and housing. So, of course, it will cause a decreasing value of vacant land availability in the municipality of Malang. As a result, the selling value of property in the municipality of Malang will increase significantly. The Residential Sector is one of the fastestgrowing property sectors, as indicated by the large number of new housing and apartments that have been started to develop in the municipality of Malang.
This research purpose is to give some knowledge about the morphological study of residential real estate development in the urban fringes context, especially at Tunggulwulung urban village. Furthermore, through this research, we can discover the most sellable type of residential real estate in the urban fringes.

One of the highest density sub-districts in the municipality of Malang is the Lowokwaru sub-district, which is caused by the existence of state campuses, which are all in the Lowokwaru sub-district. Furthermore, in this sub-district, many commercial areas support economic and social needs. It has caused many people to live in that region. However, some people choose to live in an urban fringe area because it has many advantages, which are not too crowded, but still close to the downtown area. So, many property developers are developing residential real estate projects in this area. One of the strategic urban fringe areas in the Lowokwaru sub-district is in the Tunggulwulung urban village area (Figure 1). It is due to the availability of vacant land and land use law that is still widely available compared to other urban villages in Lowokwaru subdistrict [1]. 
A morphological study is needed to find out the pattern of development of residential real estate areas in Tunggulwulung urban villages. The Tunggulwulung urban village is often used as a research target by a settlement planner, both in the formulation of studies on an environmentally friendly settlement, valuation analysis of land resources, and an assessment of the potential for regional development [1]. The morphological study of residential real estate development has not been made in this location. This study discusses changes and developments in the existing settlement. It can be seen that a pattern of changes occurs; the periodization limitation of this morphological study was between 2003 and 2019. It is enough to determine the pattern changes and development process of residential real estate development for two decades in the 21st-century, where the development of residential real estate in the municipality of Malang has rapidly increased (Figure 2).

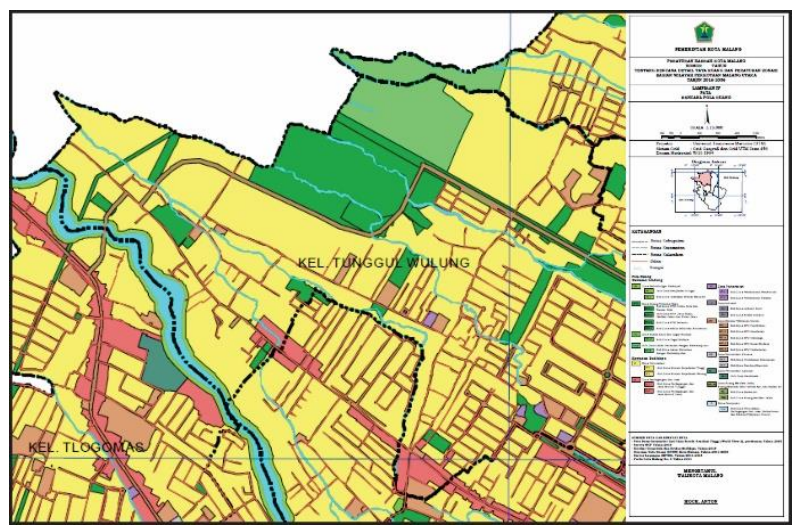

Figure 1 Tunggulwulung urban village Land Use. Source: RDTRK Pemerintah Kota Malang - BWP Malang Utara

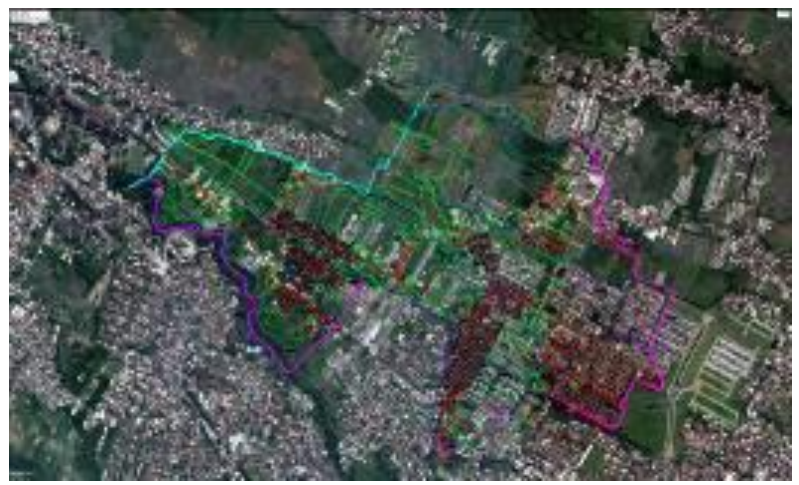

Figure 2 Tunggulwulung urban village in 2019 [2]

\section{LITERATURE REVIEW AND METHODOLOGY}

Morphology is a study of forms. In the urban context, morphology means the study of the development process and transformation of urban form and shape [3]. In the urban context, the forms and shapes have different meanings, even though they have almost the same comprehension. Form means an observable object and consists of various elements; each element can be observed that visually characteristic, while shapes are geometric features or boundaries and outlines of an object. Morphology is usually used to refer to the transformation pattern of the urban form[4].

\subsection{Urban form and shape}

To find the characteristic of urban spatial form and shape, we must know about the morphological type of urban spatial form. Urban form and shape have many types of configuration [5], which includes:

- Urban shapes "Figure 3" Consist of square shapes, rectangular shapes, fan shapes, round shapes, ribbon shapes, star/octopus shapes, and unpatterned shapes

- Urban form "Figure 4" Consists of compact form, fragmented forms, linear form, ring / chained forms, split form, and stellar form.

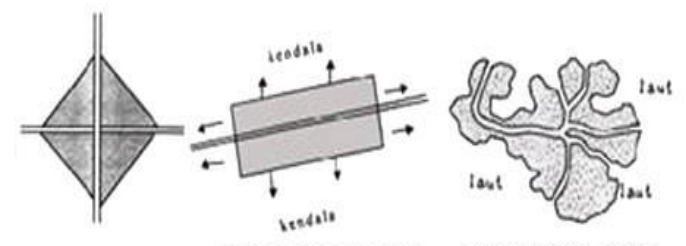

SQUARE SHAPE RECTANGULAR SHAPE UNPATTERNED SHAPE

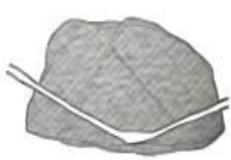

FAN SHAPE

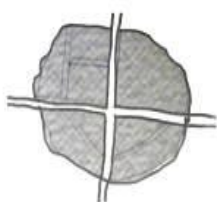

ROUND SHAPE

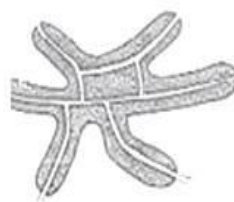

OCTOPUS/STAR SHAPE
Figure 3 Figure of the city shape [5]
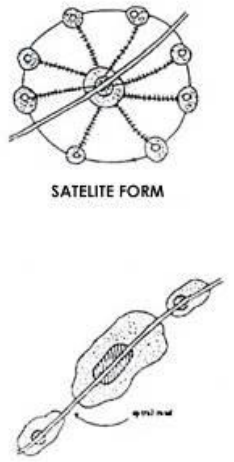

UINEAR FORM
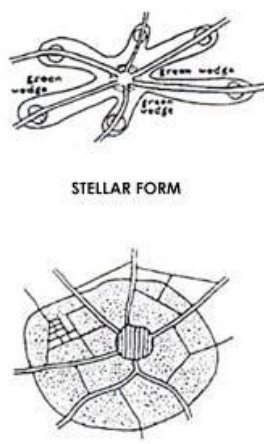

COMPACT FORM

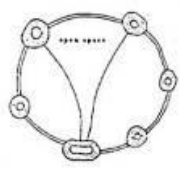

RING CHAINED FORM

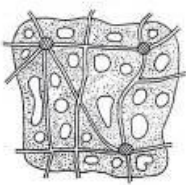

FRAGMENTED FORM

Figure 4 Figure of the city form [5] 


\subsection{Methodology}

The strategy or methodology of this research is a combined strategy with a qualitative and case study of typo-morphology [6]. This research is based on typomorphological approaches to analyze the transformation of residential real estate in the location of the study. The location of this study is based on an urban fringe area, which is more advantageous for it to be a residential settlement area [2]. Tunggulwulung urban village area has chosen because of rapid property development there. Periodization of this study started in 2003 until 2019, based on the availability of historical maps in the sources. Secondary data are obtained from the historical map feature of Google Earth Pro version 7.3.2.5776 "Figure 53' [7]. This map is used to describe the transformation of the residential real estate development in Tunggulwulung urban village. The other validation maps used are digital maps from the public work office of the municipality of Malang. The maps from Google Earth are redrawn into CAD format to improve the analysis of the transformation residential real estate area; this method had been applied in some researches about land coverage area analysis [8].

\subsection{Typo-morphological approaches}

Morphology usually does simultaneously with typological analysis (typo-morphological approaches); the approach is an integrated spatial analytical, configurational, process typological, and historical-geographical approach [9].

In the study of typo-morphological approaches have several stages that must be done gradually in the following way [10]:

- The first stage is the identification of the morphological types of land use and the relation between land, building, and the linkage system [5].

- The second stage is a morphological analysis of the results of the previous stage to find sequential changes in urban patterns at certain time limits. The result of this stage is the specific types of common characteristic land use transformation, development phases with chronological differentiation of what type belongs to the phase, and the perspective of how they are connected in the space.

\subsection{Research location description}

Tunggulwulung urban village is located in the Lowokwaru sub-district (Figure 5). The northern border is the regency of Malang and Tasikmadu urban village, the eastern border with Tunjungsekar urban village, in the southern border with Mojolangu, Jatimulyo, and Tlogomas urban village, in the western border with the regency of Malang and Tlogomas urban village. This location is one of the urban fringes in the municipality of Malang. This location was chosen because there are several prestigious real estates in the municipality of Malang. Furthermore, new residential real estate has developed rapidly in this location for the last two decades. This urban fringe location has many advantages that are because of the abundant availability of vacant land, and the situation in this area is not too crowded [11]. Tunggulwulung urban village has an area of $187 \mathrm{Ha}$ [12]. The location of this urban fringe is not too far from Soekarno-Hatta street as the central business area of Lowokwaru downtown.

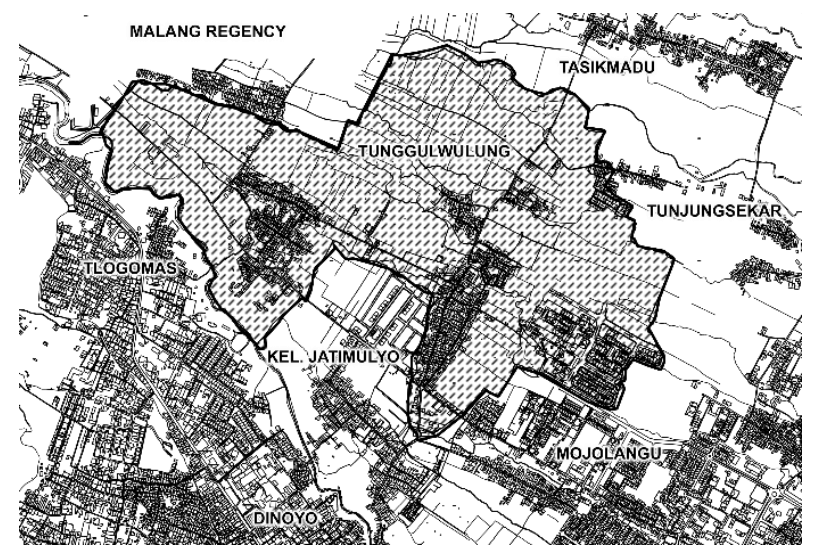

Figure 5 Location of Tunggulwulung Urban Village. Source: Peta Persil Dinas PU Kota Malang 2004

\section{RESULTS AND DISCUSSION}

In this section, we will discuss the transformation of the residential real estate area in the urban fringe, with a case study location based on Tunggulwulung urban village municipality of Malang, the discussion will be divided according to the year of the maps, which start from 2003 until 2019.

\subsection{Morphological Transformation Land Use Analysis}

To find the process of residential real estate development, we must know the transformation of land use in the location, and the analysis of land transformation will be described in the analytical maps sequentially.

1) Land use transformation between $2003 \& 2004$.

In 2003, residential areas in Tunggulwulung urban villages were dominated by informal settlements; otherwise, the largest formal settlements were developed in the southeastern area of this urban village. The characteristics of land development in this area were linear and compact form and dominated by unpatterned shapes. The area of residential land in this urban village was 45,96 $\mathrm{Ha}$ in the year of 2003 , which was $24.578 \%$ of the total area of Tunggulwulung urban village. Figure 6 shows that residential areas were separated into three regions. Those regions are formal settlements called "Permata Jingga" on the northern of Puncak Borobudur street, informal 
settlements along the Akordion street, and informal settlements surrounding the area of Arumba, Bylira, Sasando, and Karyawiguna-Saxophone street.

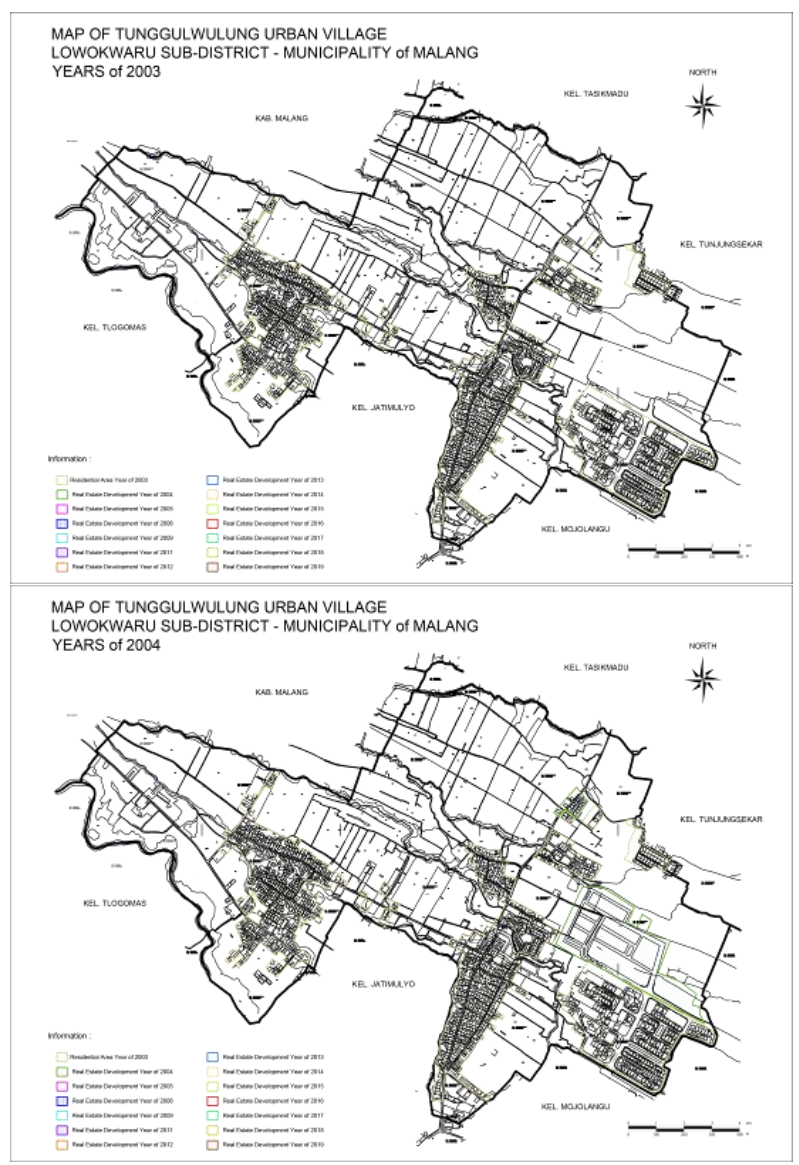

Figure 6 Analytical map of Tunggulwulung urban village year of 2003 and 2004.

In 2004, a new residential real estate was developed, and formal settlements on the northern of "Permata Jingga" existing land were opened. The characteristic of new residential development in this area was a compact form with a rectangular shape. The area of new residential real estate land in this urban village was $10,7 \mathrm{Ha}$ in the year of 2004, which was $5.72 \%$ of the total area of Tunggulwulung urban village. Figure 6 shows that several new residential areas were developed on the northern side of the existing "Permata Jingga" land, and also a formal settlement on the northern side of the Akordion street called "Graha Akordion".

2) Land use transformation between 2005 \& 2006.

In 2005, two small residential areas in Tunggulwulung urban village were developed, a new cluster on the southeastern part of the existing land of "Bumi Tunggulwulung Indah" and a new formal settlement on Arumba street were opened. The characteristics of new residential development in this area were a compact and linear form with a rectangular shape. The area of new residential real estate land in this urban village was 1,45 $\mathrm{Ha}$ in the year of 2005 , which was only $0.78 \%$ of the total area of Tunggulwulung urban village. Figure 7 shows that several new residential areas were developed behind the existing land of the "Bumi Tunggulwulung Indah" and a new formal settlement on Arumba street, called "Arumba Indah".

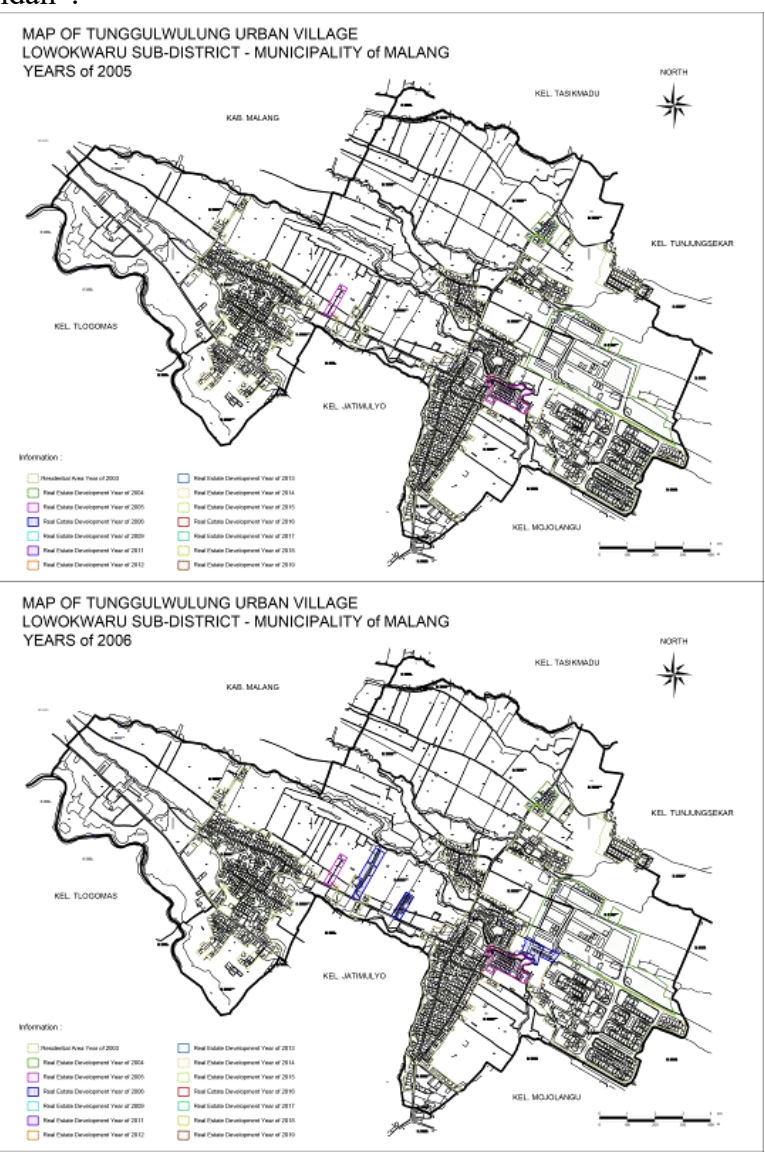

Figure 7 Analytical map of Tunggulwulung urban village year of 2005 and 2006

In 2006, three new small residential areas in Tunggulwulung urban village were developed, a new cluster on the western side of the existing land of "Permata Jingga" and two new linear formal settlements on Arumba street were opened. The characteristic of new residential development on Arumba street was a linear form with a rectangular shape. The area of new residential real estate land in this urban village was $1.63 \mathrm{Ha}$ in the year of 2006, which was only $0.87 \%$ of the total area of Tunggulwulung urban village. Figure 7 shows that a new cluster was developed behind the existing land of "Permata Jingga" land. Also, two new formal settlements on Arumba street called the "Arumba Hills Residence" and "Arumba Permai" were developed.

3) Land use transformation between $2009 \& 2011$.

In 2009 until 2011, some massively residential areas in Tunggulwulung urban village were developed, new clusters on the northeastern and western of existing land of 
"Permata Jingga" were opened and also two new formal settlements on Arumba and Akordion street were opened too. The characteristic of new residential development in this area was a compact form with a rectangular shape. The expansion of new residential real estate land was 9,42 $\mathrm{Ha}$ at the year of 2009, which was $5.04 \%$ of the total area in Tunggulwung urban village. Figure 8 shows that several new residential areas were developed on the northern and western of the existing land of "Permata Jingga". A new formal settlement on Arumba street called "M Regency", and a new formal settlement on the Akordion street called "De Green Pavilion" was developed.

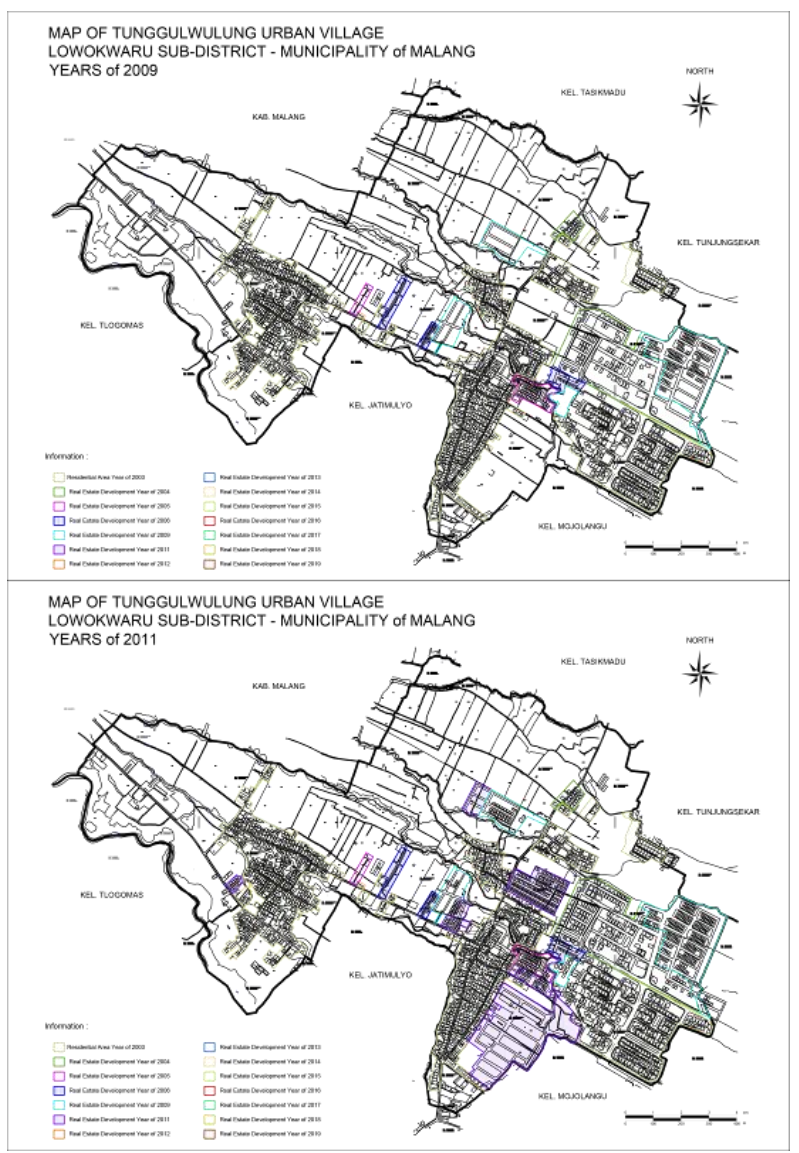

Figure 8 Analytical map of Tunggulwulung urban village year of 2009 and 2011

In 2011, the massively residential area of real estate in Tunggulwulung urban village was developed, a new exclusive cluster on the western side of the existing land of "Permata Jingga" and new formal settlements on Arumba, Saxophone, and Akordion street were opened. The characteristics of new residential development on Arumba and Saxophone street was a linear form with a rectangular shape, in the otherwise a new residential real estate on the Akordion street, which was a compact form with a rectangular shape. Furthermore, a new cluster of "De Green Pavilion" was opened in the western area of the existing land. The area of new residential real estate land in this urban village is $12 \mathrm{Ha}$ in the year of 2011, which was $6.42 \%$ of the total area of Tunggulwulung urban village. Figure 8 shows that several new clusters were developed on the western side of "Permata Jingga" land called "West Area", new formal settlements on Arumba street, called "Arumba Residence", new formal settlements on Saxophone street, called "Saxophone Hill", a new cluster on the western side of "De Green Pavilion" land, and new formal settlements on Akordion street, called "Permata Land".

4) Land use transformation between $2012 \& 2013$.

In 2012, a new residential area in Tunggulwulung urban village was developed, and a new cluster on the northern side of the Akordion street was opened. The characteristic of the new residential development in this area was a compact form with a Fan shape. The new residential real estate land was only $0.5 \mathrm{Ha}$ in the year 2012, which was only $0.27 \%$ of the total area of the Tunggulwulung urban village. Figure 9 shows that a new formal settlement was developed on the northern side of Akordion street, called the "Maharaja Residence".

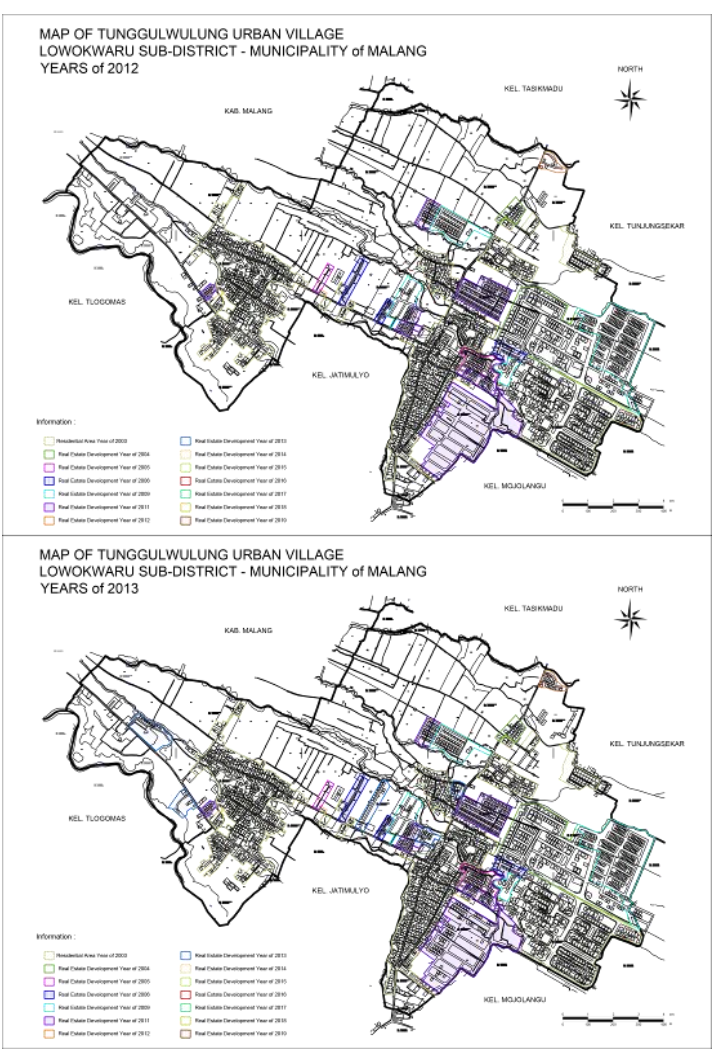

Figure 9 Analytical Map of Tunggulwulung urban village year of 2012 and 2013

In 2013, several residential areas in Tunggulwulung urban villages were developed, two new clusters on the Saxophone street, two new clusters on Arumba street, and a new cluster on Harmonika street were opened. The characteristic of new residential development in this area was a compact form with square and rectangular shapes. The expansion area of new residential real estate land was 
3.46 Ha in the year of 2013, which was $1.85 \%$ of the total area in Tunggulwulung urban village. Figure 9 shows that several new formal settlements were developed: on the northern side of the Saxophone street, called "Permata Kencana Saxophone", on the southern side of the Saxophone street, called "Saxophone River Village", on the Harmonika street, called "Graha Citra Harmony", on Arumba street was a new cluster of "Arumba Residence", and anew formal settlement on Arumba street, called "Arumba Utama Residence".

5) Land use transformation between $2014 \& 2015$. In 2014, a new residential area in Tunggulwulung urban village was developed, a new formal settlement on the southern side of the Saxophone street was opened. The characteristic of new residential development in this area was a compact form with an unpatterned shape. The new residential real estate land was only $0.8 \mathrm{Ha}$ the year of 2014 , which was only $0.43 \%$ of the total area in the Tunggulwulung urban village. Figure 10 shows that a new formal settlement was developed on the southern side of the Saxophone street, called the "Grand Mahabharata Saxophone".

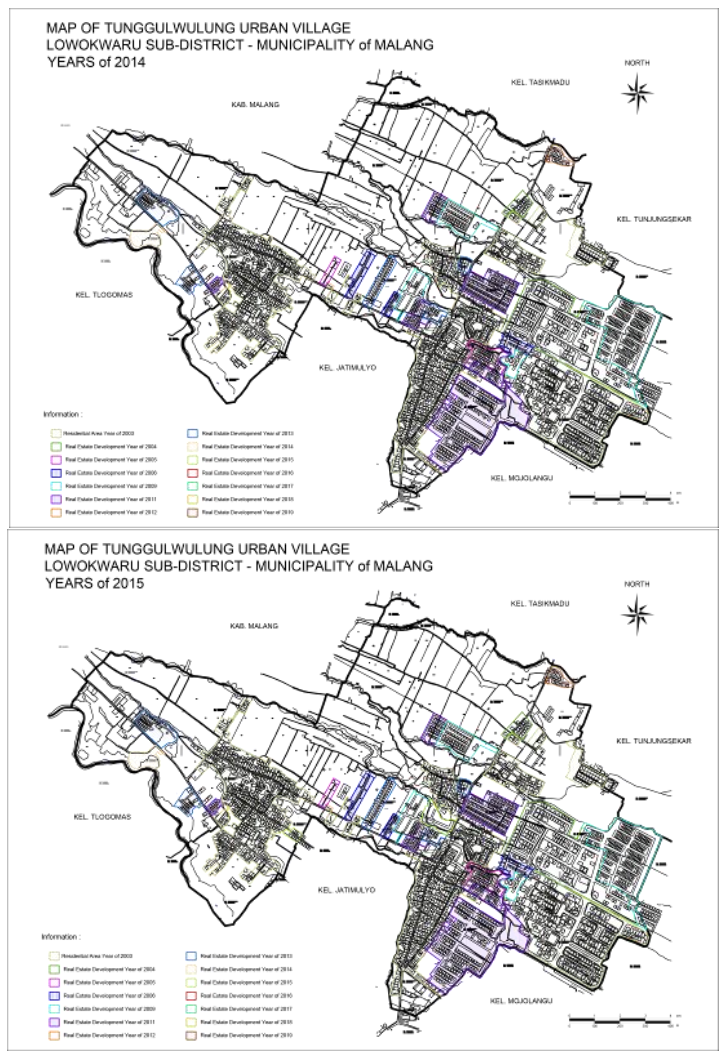

Figure 10 Analytical map of Tunggulwulung urban village year of 2014 and 2015

In 2015, two new residential areas in Tunggulwulung urban villages were developed, a new cluster on Akordion street and a new cluster on the Saxophone street was opened. The characteristic of new residential development in this area was a compact form with a rectangular shape.
The expansion of new residential real estate land was only $1.07 \mathrm{Ha}$ in the year 2015, which is only $0.57 \%$ of the total area in the Tunggulwulung urban villages. Figure 10 shows that a new cluster was developed on the western side of the "Saxophone Land" existing land. Also, new formal settlements on the Akordion street, called the "Akordeon Regency" was developed too.

6) Land use transformation between $2016 \& 2017$.

In 2016, some new area of residential real estate in Tunggulwulung urban village was developed: a new cluster on the southern and northern side of existing "Saxophone Land" cluster, a new cluster on the northern of "Arumba Utama Residence", and new formal settlements on the northern side of Akordion street were opened. The characteristic of new residential development in this area was a compact form with rectangular and unpatterned shapes. The area of new residential real estate land was $2.4 \mathrm{Ha}$ in the year 2016, which was $1.28 \%$ of the total area in Tunggulwulung urban village. Figure 11 shows that a new formal settlement was developed on the northern side of Akordion street, called "De Prima Tunggulwulung". Otherwise, a new cluster of "Saxophone Land" and "Arumba Utama Residence" was opened.

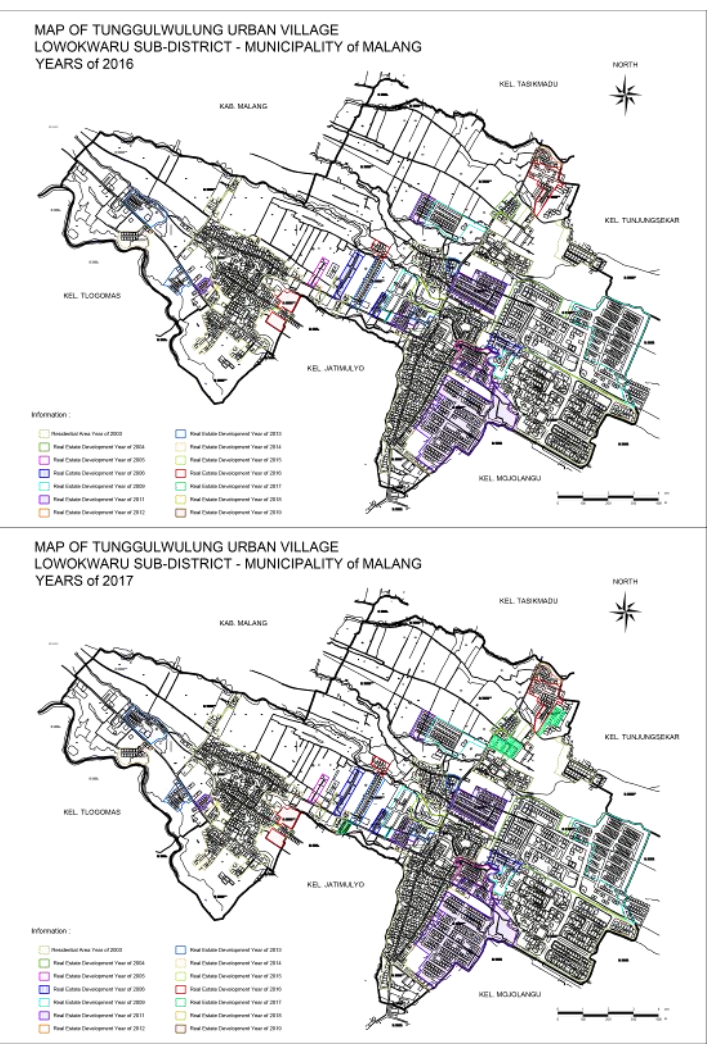

Figure 11 Analytical map of Tunggulwulung urban village year of 2016 and 2017

In 2017, three new residential areas in Tunggulwulung urban villages were developed, a new cluster on Akordion street, a new cluster on "De Prima Tunggulwulung", and a 
new cluster on southern of Arumba street were opened. The characteristic of new residential development in this area was a compact form with a rectangular shape. The expansion of new residential real estate land was $2.9 \mathrm{Ha}$ in the year 2017, which was $1.55 \%$ of the total area in Tunggulwulung urban village. Figure 11 shows that a new cluster was developed on the eastern side of "De Prima Tunggulwulung" existing land and a new formal settlement on the Akordion and Arumba street, called "Perum Permata Tunggulwulung" and "Green Arumba".

7) Land use transformation in $2018 \& 2019$.

In 2018, several expansion areas of residential real estate in Tunggulwulung urban village were developed, two new formal settlements on the northern side of Harmonika and Arumba streets were opened. The characteristic of new residential development in this area was a compact form with rectangular and unpatterned shapes. The area of new residential real estate land was $1.92 \mathrm{Ha}$ in the year of 2018, which was $1.03 \%$ of the total area in Tunggulwulung urban village. Figure 12 shows that two new formal settlement was developed on the border side of Arumba and Organ street, called "Grand Arumba" and also on the northern side of Harmonika street, called "Harmonika Indah".

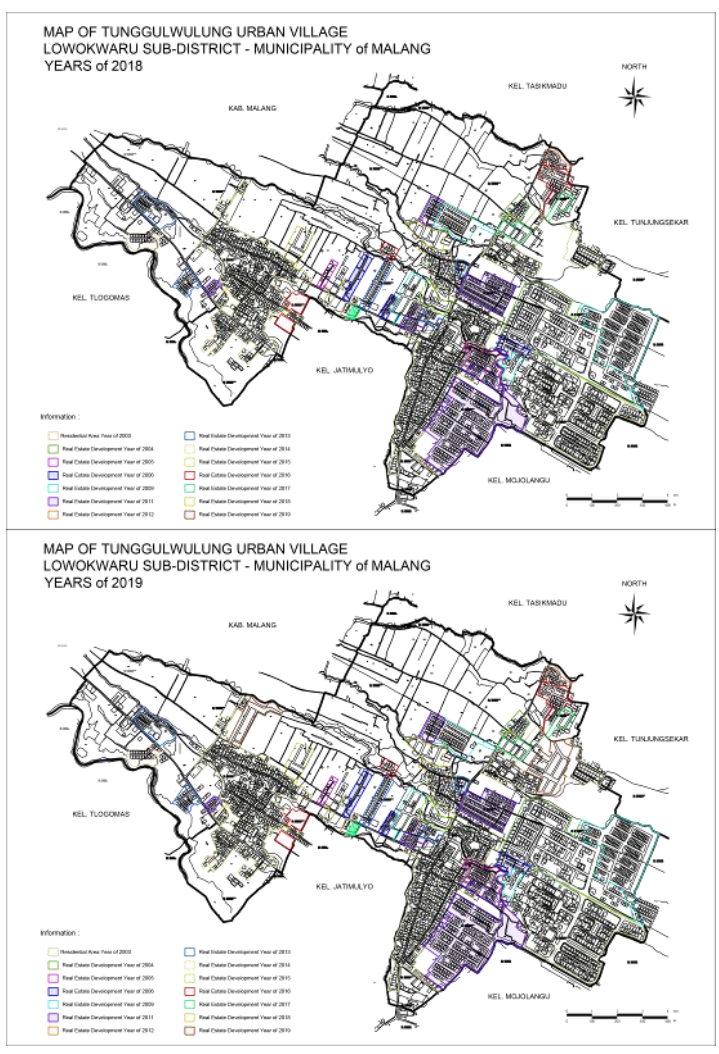

Figure 12 Analytical map of Tunggulwulung urban village year of 2018 and 2019

In 2019, two new area residential areas in Tunggulwulung urban village were developed, new formal settlements on Sasando street and new land plots on Ikan Gurami street were opened. The characteristic of new residential development in this area was a compact form with a rectangular shape. The expansion area of new residential real estate land was $3.6 \mathrm{Ha}$ in the year 2019, which was $1.92 \%$ of the total area in Tunggulwulung urban village. Figure 12 shows that new formal settlements were developed on Sasando street, called "The Rich Sasando" and new land plots on Ikan Gurami street were opened.

\subsection{Morphological Transformation Area Analysis}

To find the process of residential real estate development growing, we must know the increasing value of the residential real estate area land in the location. The analysis of land area transformation is described in Figure 13 and 14

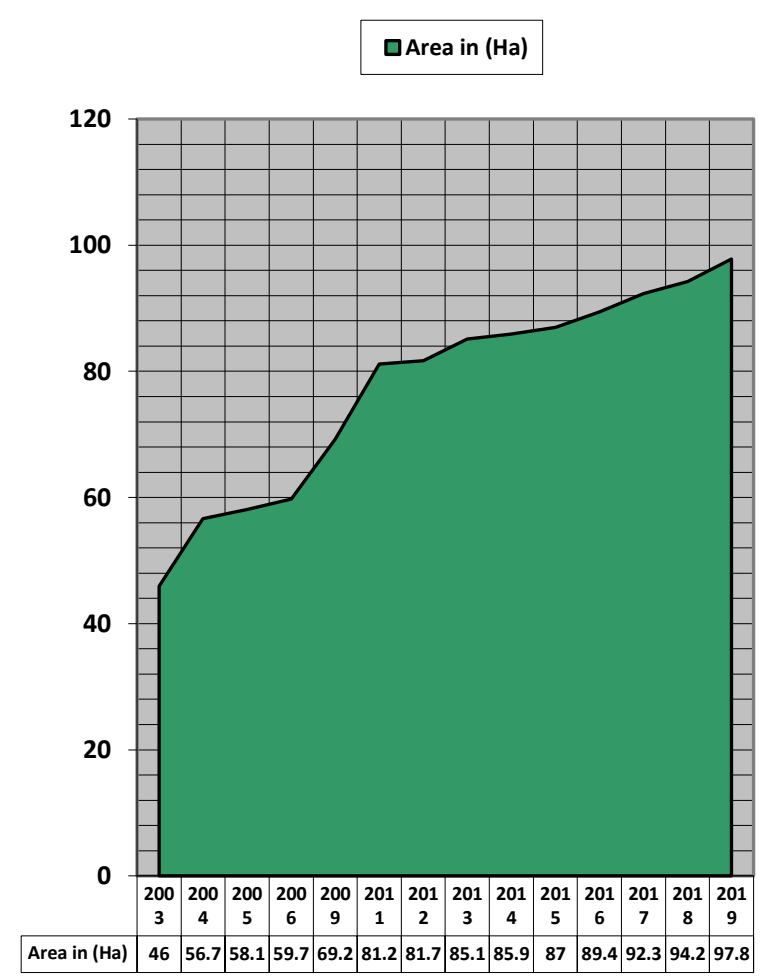

Figure 13 Chart of residential real estate land area growing in Tunggulwulung urban village between 2003-2019

Based on Figure 13, we know that the growth of residential real estate areas in Tunggulwulung urban village had increased significantly between the years 2006 and 2011. This phenomenon was caused by the development of the "Permata Jingga" residential real estate, which was located in the southeastern part of Tunggulwulung urban village. The location of "Permata Jingga" is near Soekarno - Hatta street, which is one of the Lowokwaru Central Business Area. This residential real estate is the most prestigious residential area in the 
municipality of Malang, which is middle to the upper-class residential area, with wide plots of land area and there are many public facilities for the residents. The gap value of residential real estate area land in Tunggulwulung urban village from 2003 until 2019 was $51.85 \mathrm{Ha}$, which had increased by $112.8 \%$ over the last one and half decades.

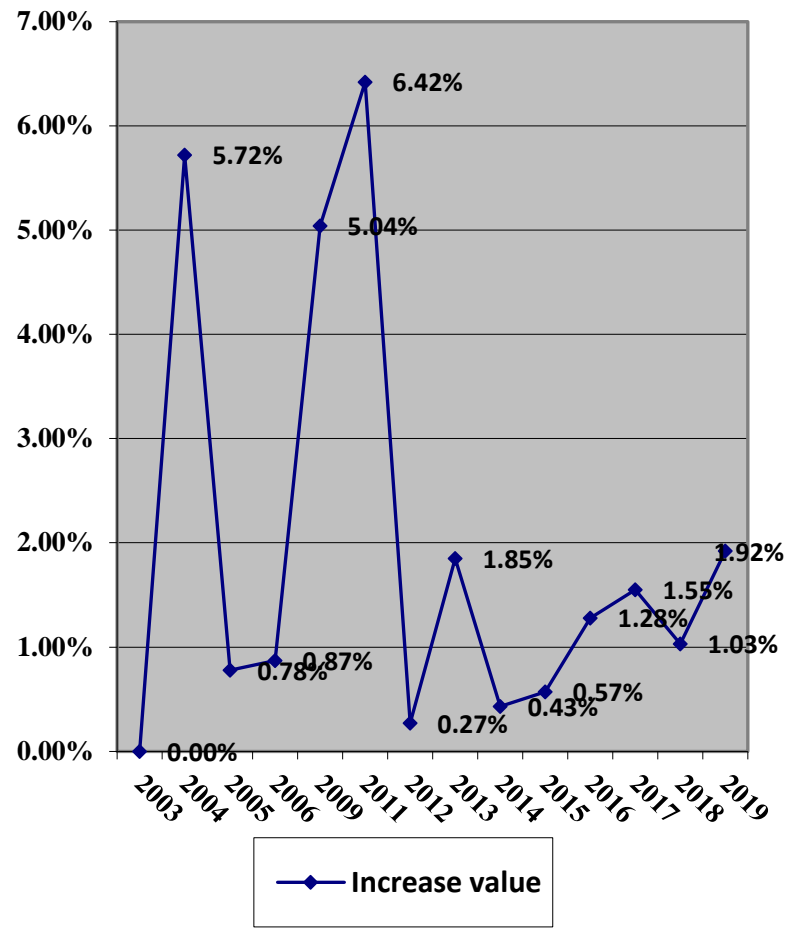

Figure 14 Chart of increased value area of the residential real estate in Tunggulwulung urban village.

Based on 'Figure 14', we know that in 2004, 2009, and 2011 , there were significant changes in the residential real estate area. In 2004 the increasing value was caused by the development of the northern cluster of "Permata Jingga" real estate. At the year of 2009 , the increasing value was caused by the development of the northeastern cluster of "Permata Jingga" real estate and also two new formal settlements, which were "De Green Pavilion" on Akordion street and "M Regency" on Arumba street. In 2011, there was the most significant increasing value of residential real estate areas that were caused by the development of several new clusters and formal settlements. The "Permata Jingga's West Area" was developed at that time, and also new formal settlements, called "Perum Permata Tunggulwulung", were developed too. Today $52.3 \%$ of the total area in Tunggulwulung urban village was a residential area.

\section{CONCLUSION}

As a result of the morphological study of residential real estate land use transformation, we know several types of forms and shapes of residential real estate in the location. There are linear and compact forms of the residential real estate, and there is a square, rectangular, fan, and unpatterned shape of it were developed. The most significant growth of residential real estate was in the southeastern region of Tunggulwulung urban village. The distance from the central business area was the main factor of the residential real estate market. The morphology of real estate residential land in Tunggulwulung urban village grew along the intercity roads. According to land use planning in Tunggulwulung urban village, the residential area was the major land use in this urban village.

Between 2006 and 2011, the most significant residential real estate area land grew in Tunggulwulung urban village, which was caused by the development of the Permata Jingga new cluster, and several new formal settlements along the intercity roads. Since 2003 until 2019, the area of residential real estate land has been increased by $112,8 \%$. In the years of 2004,2009, and 2011 there have been significantly increasing the value of residential real estate land area.

The urban fringe area is chosen for the residential settlements because of the availability of vacant lands and the good situation in this area, which was not too crowded. Furthermore, the lower land value makes the urban fringe feasible to be developed as a residential real estate area. Today, $52.3 \%$ of the total area in Tunggulwung urban village was developed as a residential area.

This research object location is only in Tunggulwulung urban village, so it can only be represented trend and culture of residential real estate morphology in this location. For the researcher or the government of the Municipality of Malang can replicable this research to complete knowledge about morphological real estate area in Malang city. It can be added knowledge to the property developers, communities, and the government of the municipality of Malang to make a decision or rule for residential development in urban fringes.

\section{ACKNOWLEDGMENT}

The author would like to thank the experts who are involved in the writing process for this research project. Without their passionate participation and input in the previous research, this research could not have been successfully conducted. Many thanks to all of the lecturers at the authors' undergraduate program at the Universitas Brawijaya and the authors' postgraduate lecturers at Sepuluh Nopember Institute of Technology for the knowledge that has been given. Without their knowledge and guidance, this research can not be completed properly.

\section{REFERENCES}

[1] Ardiansyah, M., Sasongko, I., Gai, A. M., Kontak dan Tingkat Interaksi Sosial Masyarakat Berdasarkan Tipologi Perumahan di Kelurahan Tunggulwulung dan Mojolangu Kecamatan Lowokwaru Kota Malang, 
Skripsi Fakultas Teknik Sipil dan Perencanaan Institut Teknologi Nasional, 2018.

[2] Ahmad, Dr.J., Nusrath, A., Shivamallu, D., A Literature Survey on Rural-Urban Fringe, Journal Of International Academic Research For Multidisciplinary, 2014.

[3] Carmona, M., Heath, T., OC, T., and Tisdell, S., Public Places, Urban Spaces: The Dimensions of Urban Design, Amsterdam, Architectural Press/Elsevier, 2003.

[4] Sandyangsani, P. P., Pamungkas, S.T; Wulandari, L.D, Morfologi Spasial Lingkungan di Kawasan Malabar-Merbabu Malang, Jurnal Mahasiswa Jurusan Arsitektur Universitas Brawijaya, 2017.

[5] Trancik, R., Finding lost space: Theories of Urban Design, New York, Van Nostrand Reinhold, 1986.

[6] Groat, L. N. W., D., Architectural Research Methods, Wiley, 2013.

[7] Setiawan, A., Penentuan Luas Lahan dengan Bantuan Google Earth. 2016.

[8] Wahyuni, E.D., S. Mukaromah, and L.U. W, Web GIS Tutupan Lahan Dengan Menggunakan Google Map dan Google Earth. Jurnal Sistem Informasi Dan Bisnis Cerdas (SIBC), 2017. 10.

[9] Mohamed, S., Harun, N. Z. \& Abdullah, A., Urban Morphological Analysis Framework for Conservation Planning and Management, Journal of the Malaysian Institute of Planners, 2018.

[10] Gajic, R, Urban morphology as a tool for exploring the land use in residential areas: Example of New Belgrade. The Journal of Institute of Architecture and Urban \& Spatial Planning of Serbia, 2015.

[11] Putri, M. A., Rahayu, M. J. \& Putri, R. A, Bentuk Morfologi Kawasan Permukiman Urban Fringe Selatan Kota Surakarta, Jurnal Pengembangan Kota, 2017.

[12] Badan Pusat Statistik, Kota Malang dalam Angka, Malang: Badan Pusat Stastistik Kota Malang, 2018. 